Rev Soc Esp Dolor

2014; 21(1): 65-67

\title{
Inclusión de RESED en el Î́ndice Bibliográfico MJL Medical Journal Link de North Carolina (EE. UU.)
}

Estimado Socio:

Tras esta nota podrás leer la carta que Max Keller del Índice Bibliográfico MJL Medical Journal Link de North Carolina, EE. UU. nos ha enviado. Como verás la Revista de la Sociedad Española del Dolor ha siso indexada en este índice que acoge a más de 11.000 revistas médicas que, como la nuestra, cumplen con los requisitos más exigentes en cuanto a nivel de calidad y revisión. Este es un paso en nuestro recorrido para obtener un factor de impacto que reconozca el lugar que ocupa la Revista en el mundo del dolor en habla española. Aprovecho para pedirte tu colaboración y solicitarte que nos envíes aquellos artículos científicos que quieras publicar.

\section{Medical Journal Links}

Mebane, North Carolina

January $6^{\text {th }}, 2014$

Dear Editor:

We are glad to inform you that the Revista de la Sociedad Espanola del Dolor has been recently indexed by MJL. Congratulations for an excellent journal.

With more than 11,000 peer reviewed medical journals indexed, MJL is one of the most complete, open access journal resources in the Web.

Since its creation in 2011, the number of unique visitors to MJL website has grown to over 105,000 in 2013. Physicians, biomedical scientists and other health professionals from 130+ countries count on MJL to find journals in every medical specialty.

Please, go over your journal listing in the Anesthesiology page, and let us know if corrections are needed regarding linking page, title, abbreviation or impact factor.

We thank you for your time, and appreciate your cooperation in this matter.

Best regards,

Max Keller

Web Manager

PS: If you are linking to MJL from your journal or society website, please link to MJL's Homepage page (http// www.medical-journals-links.com/) or another page of your choice. This is a great way to help MJL in reaching out to more medical researchers, professionals and students. Please, tell your colleagues and students about MJL. Thanks!

Medical Journals Links info@medical-journals-links.com

Classic Version: http://www.medical-journals-links.com Mobile version: http://m.medical-journals-links.com

North Carolina, USA 